\title{
RECIPROCATION AT WORK: \\ THE ROLE OF WORK TO FAMILY \\ ENRICHMENT AND FAMILY ROLE SALIENCE
}

\section{Aneel Kumar, Khalil Ahmed Channa, Niaz Ahmed Bhutto}

\section{Introduction}

Usually an individual performs two most prominent roles in daily life. One is the work role, other is the family role. It is not uncommon to find it difficult for an employee to balance both roles simultaneously and as a result they may face work family conflict. Following this conflict perspective, mostly studies have looked into the darker side of work family balance i.e., work family conflict (Greenhaus \& Powell, 2006; McNall, Nicklin, \& Masuda, 2010) but some researchers argued the positive side of work family interface (Aldous, 1969; Marks, 1977; Sieber, 1974). The conflict perspective of work and family role has been paid with extra attention in work place. On the other hand in the work place, there is an informal network of communications and friendship and such interpersonal relations have an influence on an individual's family role performance (Aldous, 1969). Realizing the value of positive aspect of work family interface, Greenhaus and Powell (2006), proposed a theory of work family enrichment (WFE). This theory of enrichment is gradually becoming the dominant model for studying the positive side of work family interface (Jaga \& Bagraim, 2011). Greenhaus and Powell (2006) define the concept of WFE as "the extent to which experiences in one role improve the quality of life in the other role" (p. 1). Like the work family conflict, the WFE is also considered as bi-directional i.e., work to family enrichment and family to work enrichment. "Work to family enrichment occurs when work experiences improve quality of family life, and family to work enrichment occurs when family experiences improve quality of work life" (Greenhaus \& Powell, 2006, p. 73). As this study is conducted in organizational context, the focus of this study is on work to family enrichment. The work experiences are basically the work resources which are considered as pre-requisite for experiencing the work to family enrichment (Greenhaus \& Powell, 2006). We propose that one way, the employees' work and family role performance can be improved, is by employing the Blau (1964) social exchange theory (SET) and Greenhaus and Powell (2006) WFE theory in the workplace. This study has been conducted in collectivist cultural context (Khilji, 2013). People living in collectivist society are supposed to take care of the interests of each other and these people are tightly integrated. Thus, being the collectivist context of the current study (Khilji, 2013), the application of SET (Blau, 1964) can be more prevalent in this part of world. People who work in the organizations are social individual because they work and live with each other and their lives are interdependent upon each other (Nelson \& Brice, 2008). Social exchange theory (Blau, 1964) posits that individuals and groups are induced by the social rewards (i.e., social support) they receive from others and they extend that service by reciprocating to the individuals or groups who have served them. Based on SET (Blau, 1964), we argue that if the employees working in an organization takes care of the family role of other employees than employees feel obligated to reciprocate to those who have helped them. Although, WFE theory (Greenhaus \& Powell, 2006) proposes many resources but employing the SET (Blau, 1964) in collectivist context, we argue that one of the resource within workplace which can improve performance of employees, is the social support. According to Hobfoll (Hobfoll, 1988), social support is related to "those social interactions or relationships that provide individuals with actual assistance or that embed individuals within a social system believed to provide love, caring, or a sense of attachment to a valued social group or dyad" (p. 121). 
Although, social support has already been studied as the predictor of many workplace attitudes and behaviors but the issue with social support is that previous studies (Mauno \& Rantanen, 2013; Siu et al., 2014; Tang, Siu, \& Cheung, 2014), have mostly determined the effect of general social support on outcomes. These studies have focused a little on specific type of support (i.e., emotional and instrumental) with its domain (i.e., work and family specific social support) and source (i.e., supervisory \& coworkers) taken together. The concept of emotional social support refers to "being empathetic, expressing care and concern, and listening" while instrumental support refers to "providing tangible and objective assistance" (House, 1981). Researchers have been arguing that each type of social support has distinguishing characteristics and varying effect on the outcomes (Boyar, Campbell, Mosley, \& Carson, 2014; Cohen \& Wills, 1985; House, Kahn, McLeod, \& Williams, 1985; Malecki \& Demaray, 2003). Researchers only examining overall social support may be missing the useful information that could have been gained by breaking down it into types and sources (Malecki \& Demaray, 2003). Further, in many social support studies, either the domain of social support is not specified (Malecki \& Demaray, 2003; Nelson \& Brice, 2008; Rees \& Hardy, 2004; Siu et al., 2014) or social support is conceptualized as work related domain but the measure adopted also included some family related social support items (Frese, 1999; Wadsworth \& Owens, 2007). Overall, the family related domain has been paid little attention while work and family role can equally be important for employees and performance in family role may also increase work role performance (Chen et al., 2014). It would be interesting to test the effect of across domain family related social support to increase our understanding on the contribution of family related domain. Thus, we integrate family related social support as domain, emotional and instrumental as types, and coworkers as source and propose to determent their integrative effects on workplace outcomes. This will help us to understand the varying effect of each type of family related social support from coworkers on workplace outcomes. One of the prominent workplace behavioral outcome through which employees may reciprocate the social support can be interpersonal citizenship behaviour (ICB). The concept of ICB "involve cooperative assistance for individuals in need" (Settoon \& Mossholder, 2002, p. 255). Settoon and Mossholder (2002) offered construct clarification of ICB and offered two forms of ICBs i.e., person and task focused ICB. The person-focused ICB "provides for self-esteem maintenance and deals with problems of a more personal nature" (Settoon \& Mossholder, 2002, p. 256) such as listening, showing concern \& courtesy, complementing, making extra efforts to understand problems of others while in contrast, the task-focused ICB "are more instrumental, arising in the course of work-role performance" (Settoon \& Mossholder, 2002 , p. 256) such as supplying information, providing work related advice, helping others who are left behind, assists others with heavy workload, help others with difficult tasks (Settoon \& Mossholder, 2002). The ICBs look like the prominent work place behaviors through which employees may reciprocate in the workplace because ICBs include the type of behaviors (i.e., person \& task focused) which are much similar like the contents of the types of coworkers' family related social support (i.e., emotional, instrumental) focused in this studies. Thus, the first objective of this study is to investigate the main effect of emotional and instrumental family related social supports from coworkers on person and task focused ICBs.

Although, the emotional and instrumental family related social supports from coworkers can be positively associated with ICBs as we proposed but still the mechanism linking this relationship hasn't been unpacked. Why and how the family related social support induce an employee to reciprocate by helping their fellow workers through ICBs, is yet a black box? Do all employees really need family related social support which may induce them to reciprocate? When an employee is more likely to reciprocate?

For answering the why or how interpersonal relations are mutually developed and exchanged as posited by SET (Blau, 1964), we have proposed work to family enrichment as the mediational mechanism which works like a bridge in social exchange process. We argue that the resource gains of emotional and instrumental family related social support from coworkers let employees experience work to family enrichment. Further, in turn these positive experiences of work to family 
enrichment develop the sense of indebtedness in the employees to reciprocate to their fellow workers through performing person and task focused ICBs in the workplace. Thus, the second objective of this study is to test work to family enrichment as mediator.

For answering the when an employee is more likely to reciprocate? work family enrichment (WFE) theory (Greenhaus \& Powell, 2006) proposes that individuals intentionally apply more effort to a role which is highly salient for them (Greenhaus \& Powell, 2006). As the focus of this study is on how reciprocation at work takes place through work to family enrichment, so the relevant role salience here is the family role salience. The concept of family role salience refers to "the degree to which family is central to one's life" (Carlson, Kacmar, Wayne, \& Grzywacz, 2006, p. 152). Thus, based on integration of WFE theory (Greenhaus \& Powell, 2006) with SET (Blau, 1964), we propose family role salience as the boundary condition. Under this condition, when the individuals for whom family role is highly salient, the resource gains of emotional \& instrumental family related social support from coworkers' let these employees experience work to family enrichment more. Further, these positive experiences of work to family enrichment develop the sense of indebtedness in the employees to reciprocate to their fellow workers more in the workplace through performing person and task focused ICBs more. Thus, third objective of this study is to contribute in the existing organizational behavior studies by testing a moderated mediation model.

\section{Theoretical Framework \& Hypotheses}

Generally social support is provided by the informal social network in which an individual lie. For example, one of the sources of informal social support at work place is coworker (Etzion, 1984). However, the issue with social support highlighted in previous studies is that they have mostly manifested the effect of general type of social support on workplace attitudes \& behaviors and focusing a little on specific type of support i.e., instrumental, emotional with its domain (i.e., work and family specific social support) and source (i.e., organizational, supervisor, and coworkers support) taken together (Mauno \& Rantanen, 2013; Siu et al., 2014; Tang et al., 2014). Researchers have been arguing that each of the type, source of social supports has distinguishing characteristics and varying effect on the workplace attitudes \& behaviors (Barling, MacEwen, \& Pratt, 1988; Boyar et al., 2014; Cohen \& Wills, 1985; House et al., 1985; Malecki \& Demaray, 2003; OsseiranWaines \& Elmacian, 1994). By examining overall social support, we may miss the useful information that can been acquired by testing the specific types and sources of social support (Malecki \& Demaray, 2003). Thus, first objective of this study will be contribute in the existing organizational behavior studies by integrating the domain (i.e., family related social support); types (i.e., emotional, instrumental); and coworkers as a source together and associating them to workplace outcomes. This will help us to understand the varying effect of each type of family related social support from coworkers on workplace outcomes.

As we conceptualized earlier, one of the prominent workplace behavior through which employees may reciprocate the social support is interpersonal citizenship behavior. Further, to distinguish which type of support (either emotional or instrumental) is more related to either person or task focused ICB, we hypothesize that coworkers provide the family related emotional support by creating family friendly work environment in which they offer care and concern for family life and understanding the family responsibilities of each other (Boyar et al., 2014). Hence, the work place behavior through which employees may reciprocate the emotional support can be person focused ICB because it contains the much similar type of help like emotional support. However emotional support provided to employees may incite them to reciprocate through task focused ICB as well. However, as we postulated, it is more likely to be reciprocated by person focused ICB. Although, there is some empirical evidence to support relationship between work related general social support and citizenship behavior (Chiaburu \& Harrison, 2008; Jawahar \& Stone, 2015) but focusing on specific aspects of social support we hypothesize that;

H1A: Emotional family related social support from coworkers is positively associated with person and task focused ICBs but it will be more related to person focused ICB as compared to task focused ICB. 
Similarly we propose that, as coworkers provide the family related tangible assistance to an individual through help in reducing workload (Lysaght, Fabrigar, Larmour-Trode, Stewart, \& Friesen, 2012), by switching work schedule, working in slack time to accommodate an individual's family responsibilities (Boyar et al., 2014). So the behavior through which employees may reciprocate the instrumental support in the workplace can be task focused ICB because it contains the much similar type of help-like instrumental support. However instrumental support provided to employees may incite them to reciprocate through person focused ICB as well. As we framed, it is more likely to be reciprocated by task focused ICB. Thus we hypothesize that;

H1B: Instrumental family related social support from coworkers is positively associated with ICBs (person and task focused) but it will be more related to task focused ICB as compared to person focused ICB.

Although, emotional and instrumental family related social support from coworkers may be positively associated with ICBs as we proposed, however the mechanism linking this relationship hasn't been unfolded in past studies. Why and how the family related social support induces an employee to reciprocate by helping their fellow workers through ICBs is yet a black box? Do all employees really need family related social support which may induce them to reciprocate? When an employee is more likely to reciprocate? For answering the why or how interpersonal relations are mutually developed and exchanged as posited by SET (Blau, 1964), we have proposed work to family enrichment as the mediational mechanism which works like a bridge in our proposed social exchange process. By determining work to family enrichment as mediator we seek to clarify the process through which social support influences individuals to display positive work behaviors. This mediational relationship looks like a comprehensive representation of SET (Blau, 1964). We propose that the resources gain of emotional and instrumental family related support from coworkers let employees experience work to family enrichment and in turn these positive experiences of work to family enrichment develops the sense of indebtedness in the employees to reciprocate the same assistance to their fellow workers through performing person \& task focused ICBs at work. Some previous empirical studies on the mediation have been conducted to test the work to family enrichment as a mediator (Baral \& Bhargava, 2010; Fung, Ahmad, \& Omar, 2013; McNall, Masuda, \& Nicklin, 2009; Odle-Dusseau, Britt, \& Greene-Shortridge, 2012; Tang et al., 2014). These studies have mainly augmented the social exchange theory to test work to family enrichment as a bridge in the social exchange process. Based on SET (Blau, 1964), this study further extends these mediational studies by testing work to family enrichment as the mediator between the integration of each specific type (i.e., emotional \& instrument) domain (i.e., family related), source (i.e., coworkers) of social support and ICBs (i.e., person \& task Focused). Thus we hypothesize that;

H2: The work to family enrichment will mediate the positive relationship between emotional and instrumental family related social support from coworkers and person and task focused ICBs.

For answering the question of when an employee is more likely to reciprocate? We have proposed family role salience as the moderator. WFE theory (Greenhaus \& Powell, 2006) proposed that resources generated in role $A$ are more likely to improve performance in role $B$ when role $B$ is highly salient as compared to when it is not. The WFE theory (Greenhaus \& Powell, 2006) proposed "role salience" as one of the potential moderator. The resources may be available to an individual in role A but he/ she may not be able to apply these resources to role $B$ because the role $B$ may be low in salience or secondary for him/her and it is not central to his/her life (Powell \& Greenhaus, 2006). Individuals intentionally apply more effort to a role which is highly salient for them (Carlson, Kacmar, Wayne, \& Grzywacz, 2006; Greenhaus \& Powell, 2006). As the focus of this study is how reciprocation at work takes place through work to family enrichment so the relevant role salience here is the family role salience. It refers to "the degree to which family is central to one's life" (Carlson, Kacmar, Wayne, \& Grzywacz, 2006, p. 152). Carlson et al. (2006) also tested the main effect of family role salience on the dimensions of work to 
family enrichment (i.e., development, affect and capital) and found positive significant effect of family role salience on two dimension (i.e., development and capital) but it is hard to find any empirical study testing family role salience as moderator of the relationship between work to family enrichment and its antecedents, albeit WFE proposes it as a potential moderator. Thus, based on integration of WFE theory (Greenhaus \& Powell, 2006) with SET (Blau, 1964), we propose family role salience as the boundary condition under which when the individuals for whom family role is highly salient, the resource gains of emotional and instrumental family related coworkers' support would let these employees to experience work to family enrichment more. Further these positive experiences of work to family enrichment would develop the sense of indebtedness in the employees to reciprocate the same assistance to their fellow workers more in the workplace through performing person and task focused ICBs more. Thus, overall this research contributes in the organization studies by testing a moderated mediation model. We propose to test the conditional indirect effect of emotional and instrumental family related social support from coworkers on person and task focused ICBs through work to family enrichment such that the conditional indirect effect will be more when family role is highly salient than when it is not highly salient.

H3: The conditional indirect effect of emotional and instrumental family related social support from coworkers on person and task focused ICBs through work to family enrichment will be more when family role is highly salient than when it is not highly salient.

\section{Research Design \& Methodology 2.1 Data and Sample}

The primary data is collected through the survey questionnaire in dyads from the employees and their immediate supervisors (i.e., branch managers) working in the commercial banking sector of Sindh province of Pakistan, mainly focusing on the urban area districts i.e., Karachi, Hyderabad, Sukkur, Larkana, and Khairpur, through convenient sampling method. As each of the commercial bank have thousands of branches located in different provinces of Pakistan and thousands of employees have been working in different branches all over
Pakistan, such as currently, national bank of Pakistan has 1,310 branches in Pakistan, where more than 15,000 employees have been working; the data regarding the exact number of employees working in each bank were not available, so the employees were selected through the convenient sampling method. Convenient sampling is the rational choice when the total population is unknown (De Voss, 1998) but we made sure that the number of respondents selected for current study is good enough to generalize the results. In this regard, we followed the sample size table of Saunders et al. (2011). According to Saunders et al. (2011), at 95 percent level of certainty, the sample size of 384 is calculated as the representative of the total population of more than $10,000,000$. So our sample size of 401 can be considered as the representative of total population of employees working in banking sector of Pakistan, generalizable at 95 percent level of certainty. The convenient sampling has been employed in work family studies as well (Allen, 2001; Baral \& Bhargava, 2010). Furthermore, the rationale to collect the data in dyads is that the collection of data in dyads is a procedural remedy suggested to avoid the issue of common method biases in research (Podsakoff, MacKenzie, Lee, \& Podsakoff, 2003). Another advantage of collecting data from banking sector employee is that due to close interaction between employees and their branch manager it is convenient to collect data in dyads from them. Furthermore, Aldous (1969) argued that often the wives of bankers and physicians give less salience to work as compared to family than the wives of teachers and accountants. So, employees of banking sector may seek more family related social support to experience work to family enrichment. Thus, in these circumstances it will be interesting to see how the support of branch managers and coworkers let employees experience work to family enrichment. As we discussed earlier that multi-source data is collected from employees' as well as their supervisors. However, supervisors participated only in the survey of ICBs' items while employee participated in the survey of social supports and work to family enrichment variables. This type of customary practice for administration of survey is also along the lines with some other studies (i.e., (Grandey, Cordeiro, \& Crouter, 2005; Kelloway, Gottlieb, \& Barham, 1999; 
Kiewitz, Restubog, Zagenczyk, \& Hochwarter, 2009; Restubog, Bordia, Tang, \& Krebs, 2010; Restubog, Hornsey, Bordia, \& Esposo, 2008; Suazo, 2011).

Initially around 550 questionnaires were distributed and out of which 401 properly filled questionnaires were selected for this study. Thus, over all response rate was around $72 \%$. With regards to the gender of respondents, the $88 \%$ of the respondents were male and $12 \%$ were female. The mean age of the respondents was 30 years while mean experience was 6.4 years. Every employee had 01 children on average. $53 \%$ of the respondents were married while $47 \%$ were unmarried. The reason for having almost half of unmarried sample in current study could be that the median age of marriage in Pakistan is 24.7 years (DHS, 2013) and $88 \%$ of respondent are male in this study, therefore, $53 \%$ of respondents were married while $47 \%$ were unmarried and further, the age at first marriage is increasing gradually (DHS, 2013). The increase in first marriage age can be due to gradual increase in unemployment rate in Pakistan as it is getting harder to meet the family needs due to low level of income. With regard to family setup, $83 \%$ of respondents had joint family setup while $17 \%$ were single family respondents. We also collected some useful information regarding the demographic information of supervisors (managers) of employees such as those associated with the gender. In this regard $92 \%$ of the managers were male while $8 \%$ were female. The mean age of the managers was 38 years while mean experience was 12 years. With regards to the marital status, $83 \%$ of the managers were married while $17 \%$ were unmarried.

\subsection{Measures}

All the measures are measured through the five point Likert scale questionnaires adopted for this study. All the measures are adopted from the well reputed JCR impact factor journal and permission from the authors have been taken as well. Emotional and instrumental family related supports from coworkers are measured through the six items scale (three items for emotional and three items instrumental coworkers' social support) adopted from Boyar et al. (2014). The sample items of the scale are; "My coworkers care about my family life", "My coworkers will volunteer to pick up the slack if I have to attend to family needs". Work to family enrichment is measured through the nine items scale adopted from Carlson et al. (2006). The sample items of the scale are; "My involvement in my work helps me to understand different viewpoints and this helps me be a better family member", "My involvement in my work puts me in a good mood and this helps me be a better family member", "My involvement in my work provides me with a sense of accomplishment and this helps me be a better family member". Person and task focused ICBs are measured through the fourteen items' (eight items for person focused and six items for task focused ICB) scale adopted from Settoon and Mossholder (2002). The sample items of the scale for ICBs are; "Takes time to listen to coworkers' problems and worries", "Helps coworkers who are running behind in their work activities". Previous empirical studies suggested that some demographic variables such as Gender (Daniel \& Sonnentag, 2014; Mauno \& Rantanen, 2013), Age (Daniel \& Sonnentag, 2014; Mauno \& Rantanen, 2013), number of children (Daniel \& Sonnentag, 2014; Mauno \& Rantanen, 2013), marital status (Daniel \& Sonnentag, 2014), experience (Kalliath, 2014; Tang et al., 2014) have significant association with the work to family enrichment. Further keeping in mind the collectivistic cultural context, the joint family set up can be another potential control variable. Therefore, based on previous empirical studies and the context of this study, 06 employees' demographic variables i.e., gender, age, number of children, marital status, joint family setup, experience and 04 supervisors' demographic variables i.e., gender, age, experience, marital status are included as control variables.

\subsection{Data Analysis \& Results}

The results of descriptive statistics and correlation are given in Tab. 1. The correlations between all the studied variables were moderate.

In order to check the validity of measures in our research context confirmatory factor analysis (CFA) was performed through AMOS. The fit indices included were Chi-square, Degrees of freedom, CMIN/DF, Tucker-Lewis Index (TLI), Comparative Fit Index (CFI), and Root-Mean Square Error of Approximation (RMSEA) (Hair, Black, Babin, and Anderson, 2010). When CFA was performed for the first time to check the model fit, the model fit indices were relatively poor (Chi-square $=1,551.50$, 


\section{Tab. 1: Descriptive statistics and correlations}

\begin{tabular}{|c|c|c|c|c|c|c|c|c|c|c|c|c|c|c|c|c|c|c|}
\hline $\begin{array}{c}\text { S. } \\
\text { No. }\end{array}$ & Variable & Mean & SD & 1 & 2 & 3 & 4 & 5 & 6 & 7 & 8 & 9 & 10 & 11 & 12 & 13 & 14 & 15 \\
\hline 1 & Gender & NA & $-\cdots$ & & & & & & & & & & & & & & & \\
\hline 2 & Joint Family Setup & NA & $\ldots$ & .03 & & & & & & & & & & & & & & \\
\hline 3 & Marital Status & NA & - & $-.15^{\star \star}$ & $.18^{\star \star}$ & & & & & & & & & & & & & \\
\hline 4 & Number of Children & 01 & 1.19 & $-.10^{\star}$ & $.19^{\star \star}$ & $.61^{\star *}$ & & & & & & & & & & & & \\
\hline 5 & Age & 30 & 7.27 & $-.16^{*}$ & $.25^{* \star}$ & $.56^{* \star}$ & $.75^{* *}$ & & & & & & & & & & & \\
\hline 6 & Experience & 6.45 & 6.79 & -.08 & $.24^{* \star}$ & $.49^{* \star}$ & $.73^{\star *}$ & $.89^{* *}$ & & & & & & & & & & \\
\hline 7 & Supervisor's Gender & NA & -- & $.12^{\star \star}$ & .09 & -.04 & -.04 & -.03 & .00 & & & & & & & & & \\
\hline 8 & Supervisor's Age & 37.72 & 7.91 & .06 & .06 & .08 & $.26^{* *}$ & $.22^{\star *}$ & $.22^{\star *}$ & $-.18^{* *}$ & & & & & & & & \\
\hline 9 & Supervisor's Experience & 12.36 & 7.53 & $.14^{\star \star}$ & .08 & .07 & $.24^{* *}$ & $.21^{* *}$ & $.23^{* *}$ & -.09 & $.89^{* *}$ & & & & & & & \\
\hline 10 & Supervisor's Marital Status & NA & --- & -.02 & .07 & .08 & $.11^{*}$ & $.11^{\star \star}$ & $.10^{*}$ & $-.15^{* *}$ & $.34^{\star *}$ & $.38^{\star *}$ & & & & & & \\
\hline 11 & Emotional FRCS & 3.70 & 0.90 & -.01 & .04 & -.00 & .00 & -.00 & -.00 & -.06 & .00 & -.00 & .04 & & & & & \\
\hline 12 & Instrumental FRCS & 3.52 & 0.91 & .05 & .06 & .00 & -.07 & -.05 & -.04 & -.08 & $-.10^{*}$ & -.06 & .06 & $.60^{* *}$ & & & & \\
\hline 13 & Family Role Salience & 4.15 & 0.89 & .07 & .04 & .02 & .05 & .00 & -.01 & $-.14^{* *}$ & .02 & .05 & .07 & $.14^{* *}$ & $.14^{\star *}$ & & & \\
\hline 14 & Work to Family Enrichment & 3.62 & 0.78 & .04 & -.01 & -.00 & .00 & -.02 & .02 & -.08 & -.02 & -.01 & -.08 & $.61^{* *}$ & $.58^{\star *}$ & $.28^{\star \star}$ & & \\
\hline 15 & Person Focused ICB & 3.74 & 0.73 & -.00 & .07 & .04 & .04 & .04 & .03 & $-.13^{* *}$ & .06 & .03 & .03 & $.41^{* *}$ & $.32^{\star *}$ & $.12^{* \star}$ & $.41^{\star *}$ & \\
\hline 16 & Task Focused ICB & 3.62 & 0.79 & .08 & .03 & -.05 & -.09 & $-.12^{*}$ & -.09 & $-.11^{*}$ & .00 & .00 & -.01 & $.30^{\star *}$ & $.33^{* *}$ & $.09^{\star *}$ & $.35^{* *}$ & $.59^{* \star}$ \\
\hline
\end{tabular}

Source: own

Note: $\mathrm{N}=401 ;{ }^{* *}=\mathrm{p}<0.01$ level, ${ }^{*}=\mathrm{p}<0.05$ level, NA = Not Applicable, FRCS = Family Related Support from Coworkers, ICB $=$ Interpersonal Citizenship Behaviour.

\section{Tab. 2: Reliability and validity}

\begin{tabular}{l|c|c|c|c}
\multicolumn{1}{c|}{ Variable } & CR & AVE & MSV & ASV \\
\hline Emotional FRCS & .82 & .61 & .48 & .26 \\
Instrumental FRCS & .82 & .61 & .48 & .25 \\
Family Role Salience & .89 & .67 & .09 & .04 \\
Work to Family Enrichment & .93 & .58 & .46 & .27 \\
Person Focused ICB & .91 & .56 & .44 & .20 \\
Task Focused ICB & .92 & .67 & .44 & .17 \\
\hline
\end{tabular}

$\mathrm{CR}=$ Composite Reliability, AVE = Average Variance Extracted, MSV = Maximum Shared Squared Variance, ASV = Average Shared Squared Variance; FRCS = Family Related Support from Coworkers; ICB = Interpersonal citizenship behaviour

Degrees of freedom $=545, \mathrm{CMIN} / \mathrm{DF}=2.84$; $\mathrm{CFI}=.89 ; \mathrm{TLI}=.88 ; \mathrm{RMSEA}=.06$ ) but after removing the two items of family role salience with low factor loadings, the model fit indices improved and were well within the acceptable level (Chi-square $=1,111.17$, Degrees of freedom $=470, \mathrm{CMIN} / \mathrm{DF}=2.36, \mathrm{CFI}=.93$, $\mathrm{TLI}=.92, \mathrm{RMSEA}=.05$ ).

We checked the composite reliability, discriminant and convergent validity of the measurement scales following the procedure recommended by Hair et al. (2010). According to this procedure a measure is said to have convergent validity when its average variance extracted (AVE) is .5 or above. A construct has the reliability $(C R)$ when its composite reliability is .7 or above while a construct is said to have discriminant validity when maximum shared squared variance (MSV), and average shared squared variance (ASV) is less than the AVE. Our all the measures fulfilled these criteria. The results are given in Tab. 2 . 
In order to check the issue of common method variance, the common latent factor test was conducted (Hameed, Roques, \& Arain, 2013; Podsakoff et al., 2003). The results of common latest factor test exhibited around 14\% shared variance among all variables and there was no further improvement in model fit. Thus there was no serious issue of common method variance.

\section{Results}

In hypothesis $1 \mathrm{~A}$, we proposed that emotional family related social support from coworkers is positively associated with person and task focused ICBs but more positively related to person focused ICB. The control variable of supervisory gender showed significant correlation with person focused ICB so it was further included in regression analysis. Furthermore, the regression analysis results showed that emotional family related social support from coworkers $(\beta=.35, p<.00)$ has positive and significant association with person focused ICB while instrumental $(\beta=.10, p<.10)$ has positive and significant association with person focused ICB only at 10 percent level of significance $(p<.10)$. The effect of emotional was more than the instrumental coworkers' family related social support on person focused ICB. Overall, the model explained around 17 percent of significant variance by emotional \& instrumental social supports in person focused ICB.

In hypotheses 1B, we proposed that instrumental family related social support from coworkers is positively associated with person and task focused ICB but it will be more related to task focused ICB as compared to person focused ICB. The control variable of employees' age and supervisory gender showed significant correlations with task focused ICB, thus, they were further included in regression analysis. Furthermore, the regression analysis results showed that emotional $(\beta=.16, p<.00)$ and instrumental $(\beta=.23, p<.00)$ family related social supports from coworkers have positive and significant association with task focused ICB. The effect of instrumental was more than the emotional coworkers' support on task focused ICB. Overall, model explained around 12 percent of significant variance by two types of social supports in task focused ICB. Thus, hypotheses $1 \mathrm{~A}$ and $1 \mathrm{~B}$ were fully supported. The results are given in Tab. 3 and 4 .

\section{Results for testing main effect of emotional and instrumental family related Tab. 3: social supports from coworkers on person focused interpersonal citizenship behavior}

\begin{tabular}{l|c|c|c|c|c|c}
\multicolumn{1}{c|}{ Variable } & $\mathbf{B}$ & $\mathbf{S E}$ & $\boldsymbol{\beta}$ & $\mathbf{p}$ & $\mathbf{R}^{\mathbf{2}}$ & $\Delta \mathbf{R}$ \\
\hline Step 1 - Controls & & & & & & \\
Supervisory Gender & -.37 & .13 & -.13 & .00 & $.02^{\star *}$ & $.02^{\star *}$ \\
Step 2 - Main Effect & & & & & \\
Supervisory Gender & -.29 & .12 & -.11 & .02 & & \\
Emotional FRCS & .29 & .04 & .35 & .00 & & $.19^{* *}$ \\
Instrumental FRCS & .08 & .04 & .10 & .06 & $.17^{* *}$ \\
\hline
\end{tabular}

Source: own

Note: $N=401 ;$ FRCS $=$ Family Related Support from Coworkers; ${ }^{* *}=p<0.01$ level

In $\mathrm{H} 2$, we proposed that work to family enrichment will mediate the positive relationship between emotional and instrumental family related social supports from coworkers and ICBs (person and task focused). The mediation analysis was conducted following the process of Preacher et al. (2007) using their PROCESS macro for SPSS (Hayes, 2012). The mediational analysis results showed the significant indirect effect of emotional (unstandardized $\beta=.08 ;$ S.E $=.02 ; p<.05)$ and instrumental (unstandardized $\beta=.06 ;$ S.E $=.02 ; p<.05$ ) family related social supports from coworkers on person focused ICB. The indirect effect of emotional was more than the instrumental coworkers' support on person focused ICB. The results are given in Tab. 5 .

The mediational analysis results also showed the significant indirect effect of emotional (unstandardized $\beta=.07$; S.E $=.02$; 
Results for testing main effect of emotional and instrumental family related

Tab. 4: social supports from coworkers on task focused interpersonal citizenship behavior

\begin{tabular}{l|c|c|c|c|c|c}
\multicolumn{1}{c|}{ Variable } & B & SE & $\boldsymbol{\beta}$ & $\mathbf{p}$ & $\mathbf{R}^{2}$ & $\Delta \mathbf{R}$ \\
\hline Step 1 - Controls & & & & & & \\
Age & -.01 & .00 & -.13 & .01 & & \\
Supervisory Gender & -.36 & .14 & -.12 & .01 & $.03^{\star *}$ & $.03^{\star *}$ \\
Step 2 - Main Effect & & & & & & \\
Age & -.01 & .00 & -.11 & .01 & & \\
Supervisory Gender & -.27 & .14 & -.09 & .05 & & \\
Emotional FRCS & .14 & .05 & .16 & .00 & & $.15^{\star *}$ \\
Instrumental FRCS & .20 & .05 & .23 & .00 & $.12^{\star *}$ \\
\hline
\end{tabular}

Note: $\mathrm{N}=401 ; \mathrm{FRCS}=$ Family Related Support from Coworkers; ${ }^{* *}=\mathrm{p}<0.01$ level

Tab. 5:

Results for testing mediating effect of work to family enrichment on relationship between social supports and person focused interpersonal citizenship behavior - $\mathrm{BC} 95 \% \mathrm{Cl}$ (with 5,000 bootstrap)

\begin{tabular}{l|c|c|c|c|c|c}
\multicolumn{1}{c|}{ Variable } & B & SE & Lower & Upper & $\mathbf{p}$ & $\mathbf{R}^{\mathbf{2}}$ \\
\hline Emotional FRCS & & & & & & \\
Total effects & .29 & .04 & .19 & .37 & .00 & $.19^{* *}$ \\
Direct Effects & .21 & .04 & .10 & .30 & .00 & \\
Indirect Effects & .08 & .02 & .03 & .13 & & \\
Instrumental FRCS & & & & & \\
Total effects & .08 & .04 & -.00 & .17 & .06 & $.19^{* *}$ \\
Direct Effects & .02 & .04 & -.07 & .11 & .65 & \\
Indirect Effects & .06 & .02 & .02 & .11 & & \\
\hline
\end{tabular}

Source: own

BC = Biased Corrected; $\mathrm{Cl}=$ Confidence Intervals; S.E = Standard Error; $\mathrm{N}=401 ;{ }^{*}=\mathrm{p}<0.01$ level; FRCS $=$ Family Related Support from Coworkers

Tab. 6:

Results for testing mediating effect of work to family enrichment on relationship between social supports and task focused interpersonal citizenship behavior - $\mathrm{BC} 95 \% \mathrm{Cl}$ (with 5,000 bootstrap)

\begin{tabular}{l|c|c|c|c|c|c}
\multicolumn{1}{c|}{ Variable } & B & SE & Lower & Upper & $\mathbf{p}$ & $\mathbf{R}^{\mathbf{2}}$ \\
\hline Emotional FRCS & & & & & & \\
Total effects & .14 & .05 & .04 & .24 & .00 & $.15^{\star *}$ \\
Direct Effects & .07 & .05 & -.04 & .17 & .23 & \\
Indirect Effects & .07 & .02 & .02 & .14 & & \\
Instrumental FRCS & & & & & \\
Total effects & .20 & .05 & .09 & .29 & .00 & $.15^{\star *}$ \\
Direct Effects & .14 & .05 & .03 & .23 & .01 & \\
Indirect Effects & .06 & .02 & .02 & .11 & & \\
\hline
\end{tabular}


$p<.05$ ) and instrumental (unstandardized $\beta=.06$; S.E $=.02 ; p<.05$ ) family related social supports from coworkers on task focused ICB. Again the indirect effect of emotional was more than the instrumental coworkers' support on task focused ICB. Thus hypotheses 2 was fully supported. The results are given in Tab. 6 .

In $\mathrm{H} 3$, we proposed that the conditional indirect effect of emotional and instrumental family related social support from coworkers on the ICBs (person \& task focused) through work to family enrichment will be more when family role is highly salient than when it is not highly salient. The moderated mediation analysis was conducted following the process of Preacher et al. (2007) using their PROCESS macro for SPSS (Hayes, 2012). According to Hayes (2012) if the conditional indirect effect of moderator is determined in the first stage path $A(X \rightarrow M)$ of the mediating relationship $(\mathrm{X} \rightarrow \mathrm{M} \rightarrow \mathrm{Y})$ than model number 7 of process macro is run to determine the conditional indirect effect (Hayes, 2012). However, the significant simple interaction effect is not a pre-requisite for conditional indirect effect (Preacher et al., 2007). The evidence of conditional indirect effect of $X$ on $Y$ at different values of moderator (plus/minus one standard deviation from mean) cannot be excluded if the bootstrapped confidence intervals does not include zero (Hayes, 2012). The moderated mediation analysis results showed the significant simple interaction of emotional $(\beta=.13$; S.E $=.03$; $p<.00)$ and instrumental $(\beta=.09 ;$ S.E $=.03$; $p<.01)$ family related social support from coworkers with family role salience on work to family enrichment. We plotted the slopes to check the effects of moderator on relationship between emotional and instrumental family related social support from coworkers and work to family enrichment at different levels of moderator. The slope showed that the relationship became stronger when family role salience was high as compared to when it was low. The Slopes are given in Fig. 1 and 2.

Further, the moderated mediation bootstrapped results for the conditional indirect effect of emotional family related social support from coworkers on person focused ICB through work to family enrichment at different values of moderator - family role salience were i.e., at $-1 \mathrm{SD}(\beta=.05 ; \mathrm{LL}=.01 \& \mathrm{UL}=.09)$, at Mean $(\beta=.07 ; \mathrm{LL}=.03 \& \mathrm{UL}=.12)$, and at $+1 \mathrm{SD}$ $(\beta=.10 ; \mathrm{LL}=.04 \& \mathrm{UL}=.16)$. As it can be observed that the confidence intervals do not include zero at low (-1 SD), medium (mean) and high level (+1 SD) of moderator. Thus, the conditional indirect effects were significant at all

\section{Fig. 1: Slope for interactive effect of emotional family related support from coworkers and family role salience on work to family enrichment}

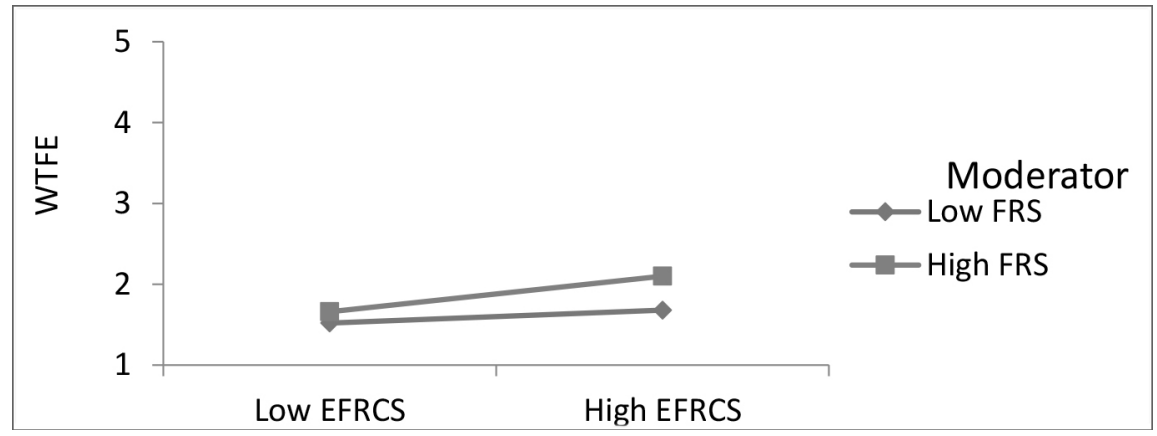

Source: own

Note: WTFE $=$ Work to family enrichment; FRS $=$ Family role salience; EFRCS $=$ Emotional Family Related Support from Coworkers 


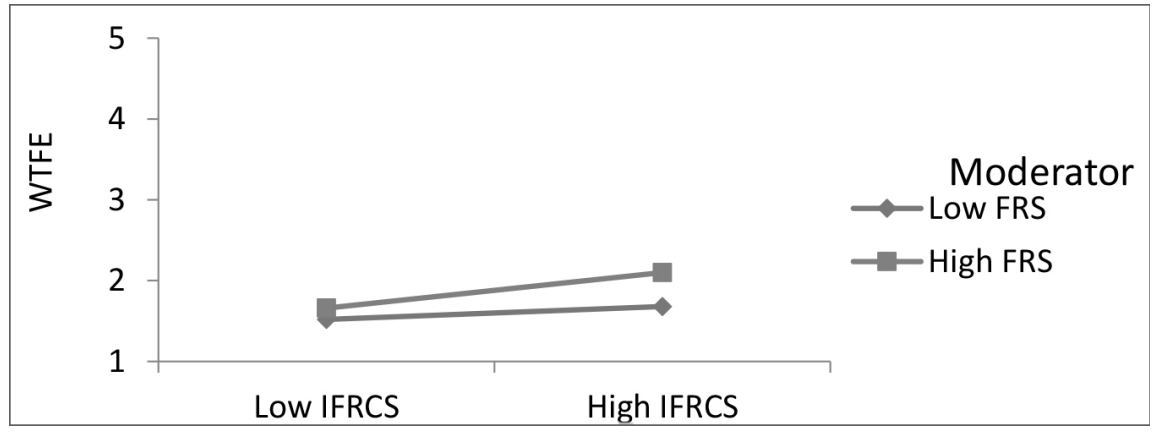

Source: own

Note: WTFE $=$ Work to family enrichment; FRS = Family role salience; IFRCS = Instrumental Family Related Support from Coworkers

Tab. 7:

Conditional indirect effect of family role salience on the relationship between social supports and person focused interpersonal citizenship behaviour through mediation of work to family enrichment - (with 5,000 bootstrap) $\mathrm{BC} 95 \% \mathrm{Cl}$

\begin{tabular}{|c|c|c|c|c|c|c|}
\hline Variable & B & SE & Lower & Upper & $\mathbf{p}$ & $\mathbf{R}^{2}$ \\
\hline \multicolumn{7}{|l|}{ Simple Moderation Effect } \\
\hline Emotional FRCS & .34 & .03 & .26 & .41 & .00 & $.50^{\star *}$ \\
\hline Family Role Salience & .19 & .03 & 12 & .25 & .00 & \\
\hline EFRCS $\times$ FRS & .13 & .03 & .06 & 19 & .00 & \\
\hline \multirow{3}{*}{\multicolumn{7}{|c|}{$\begin{array}{l}\text { Conditional Indirect Effect } \\
\text { of Emotional FRCS at selected } \\
\text { values of moderator }\end{array}$}} \\
\hline & & & & & & \\
\hline & & & & & & \\
\hline$-1 \mathrm{SD}$ & .05 & .01 & 01 & .09 & & \\
\hline Mean & .07 & .02 & .03 & 12 & & \\
\hline$+1 \mathrm{SD}$ & .10 & .03 & .04 & .16 & & \\
\hline \multicolumn{7}{|l|}{ Simple Moderation Effect } \\
\hline Instrumental FRCS & .28 & .03 & 19 & .35 & .00 & $.50^{\star *}$ \\
\hline Family Role Salience & .17 & .03 & 10 & .23 & .00 & \\
\hline IFRCS x FRS & .09 & .03 & .01 & 15 & 01 & \\
\hline Conditional Indirect Effect & & & & & & \\
\hline \multicolumn{7}{|l|}{ of Instrumental FRCS at selected } \\
\hline values of moderator & & & & & & \\
\hline$-1 \mathrm{SD}$ & .04 & .02 & 01 & .09 & & \\
\hline Mean & .06 & .02 & .02 & 11 & & \\
\hline$+1 \mathrm{SD}$ & .08 & .02 & .03 & 14 & & \\
\hline
\end{tabular}


levels of moderator - family role salience, which means the overall possibility of conditional indirect effect of coworkers' emotional family related social support on person focused ICB cannot be excluded. The results are given in Tab. 7.

The moderated mediation bootstrapped results for conditional indirect effect of instrumental family related social support from coworkers on person focused ICB through work to family enrichment at different values of moderator - family role salience were i.e., at $-1 \mathrm{SD}(\beta=.04 ; \mathrm{LL}=.01 \& \mathrm{UL}=.09)$, at Mean $(\beta=.06 ; \mathrm{LL}=.02 \& \mathrm{UL}=.11)$, and at $+1 \mathrm{SD}$ $(\beta=.08 ; \mathrm{LL}=.03 \& \mathrm{UL}=.14)$. As it can be observed that the confidence intervals do not include zero at low (-1 SD), medium (mean) and high level (+1 SD) of moderator. Thus, conditional indirect effects were significant at all levels of moderator - family role salience which means the overall possibility of conditional indirect effect of instrumental family related social support from coworkers on person focused ICB cannot be excluded. The results are given in Tab. 7 .

Further, as the simple interaction effects are almost same as discussed earlier because, the independent variables (i.e., two types of social support), moderator (family role salience), the mediator (work to family enrichment) are same except the dependent variable (task focused ICB). Moderation occurs at path A of mediation, so there is no need to either explain or plot their graphs again. Further, the moderated mediation bootstrapped results for the conditional indirect effect of emotional family related social support from coworkers on task ICB through work to family enrichment at different values of moderator - family role salience were i.e., at $-1 \mathrm{SD}(\beta=.05 ; \mathrm{LL}=.01 \& \mathrm{UL}=.09)$, at Mean $(\beta=.07 ; \mathrm{LL}=.02 \& \mathrm{UL}=.13)$, and at $+1 \mathrm{SD}$ $(\beta=.10 ; \mathrm{LL}=.02 \& \mathrm{UL}=.17)$. As it can be observed that the confidence intervals do not include zero at low (-1 SD), medium (mean) and high level (+1 SD) of moderator. Thus, conditional indirect effects were significant at all levels of moderator - family role salience which means the overall possibility of conditional indirect effect of emotional family related social support from coworkers on task focused ICB cannot be excluded. The results are given in Tab. 8. Further, the moderated mediation bootstrapped results for the conditional indirect effect of instrumental family related social support from coworkers on task focused ICB through work to family enrichment at different values of moderator - family role salience were i.e., at $-1 \mathrm{SD}(\beta=.04 ; \mathrm{LL}=.01 \& \mathrm{UL}=.09)$, at Mean $(\beta=.06 ; \mathrm{LL}=.02 \& \mathrm{UL}=.11)$, and at $+1 \mathrm{SD}(\beta=.07 ; \mathrm{LL}=.02 \& \mathrm{UL}=.14)$. As it can be observed from the results given in Tab. $5 B$, that the confidence intervals do not include zero at low (-1 SD), medium (mean) and high level (+1 SD) of moderator. Thus conditional indirect effects were significant at all levels of moderator - family role salience which means the overall possibility of conditional indirect effect of instrumental family related social support from coworkers on task focused ICB cannot be excluded. The results are given in Tab. 8. Therefore, $\mathrm{H} 3$ for moderated mediation hypothesis was supported for all proposed relationships.

\section{Discussion}

Our study found the significant role of emotional and instrumental family related social supports from coworkers in influencing employees to reciprocate by performing the person focused as well as task focused ICBs within the organization. Although, the relationship between coworkers' general social support and citizenship behavior has already been tested by Chiaburu and Harrison (Chiaburu \& Harrison, 2008), but we responded to the calls placed to study the varying effect of specific type of support (i.e., emotional, instrumental) with its domain (i.e., work or family) and sources (i.e., supervisory, coworkers) taken together (Boyar et al., 2014; Malecki \& Demaray, 2003). We have extended the previous research by testing the effect of emotional and instrumental family related social supports from coworkers on two specific types of citizenship behaviors (i.e., person \& task focused ICBs). Our findings showed that employees fulfilled the norms of reciprocity by helping out to those who provided them either emotional or instrumental support and further, the emotional help was reciprocated more with the similar type of help displaying person focused ICB while instrumental was reciprocated more with the similar type of help displaying task focused $I C B$, as we proposed. The testing of varying effects provided underpinnings on which type of coworkers' family related social support either emotional or instrumental contributes more to either person or task focused ICB. 
Conditional indirect effect of family role salience on the relationship between

Tab. 8: social supports and task focused Interpersonal citizenship behaviour through mediation of work to family enrichment - (with 5,000 bootstrap) $\mathrm{BC} 95 \% \mathrm{Cl}$

\begin{tabular}{|c|c|c|c|c|c|c|}
\hline Variable & B & SE & Lower & Upper & $\mathbf{p}$ & $\mathbf{R}^{2}$ \\
\hline \multicolumn{7}{|l|}{ Simple Moderation Effect } \\
\hline Emotional FRCS & .34 & .03 & 26 & 41 & .00 & $.50^{* *}$ \\
\hline Family Role Salience & .19 & .03 & .12 & .26 & .00 & \\
\hline EFRCS x FRS & .13 & .03 & .06 & .20 & .00 & \\
\hline \multirow{2}{*}{\multicolumn{7}{|c|}{$\frac{\text { Conditional Indirect Effect of }}{\text { Emotional FRCS at selected values }}$}} \\
\hline & & & & & & \\
\hline \multicolumn{7}{|l|}{ of moderator } \\
\hline$-1 \mathrm{SD}$ & .05 & .02 & .01 & .09 & & \\
\hline Mean & .07 & .02 & .02 & .13 & & \\
\hline$+1 \mathrm{SD}$ & .10 & .03 & .02 & 17 & & \\
\hline \multicolumn{7}{|l|}{ Simple Moderation Effect } \\
\hline Instrumental FRCS & .28 & .03 & 19 & .35 & .00 & $.49^{* *}$ \\
\hline Family Role Salience & .17 & .03 & .10 & .23 & .00 & \\
\hline IFRCS $x$ FRS & .09 & .03 & 01 & 15 & .01 & \\
\hline \multirow{2}{*}{\multicolumn{7}{|c|}{$\begin{array}{l}\text { Conditional Indirect Effect of } \\
\text { Instrumental FRCS at selected }\end{array}$}} \\
\hline & & & & & & \\
\hline values of moderator & & & & & & \\
\hline$-1 \mathrm{SD}$ & .04 & .02 & .01 & .09 & & \\
\hline Mean & .06 & .02 & .02 & 11 & & \\
\hline$+1 \mathrm{SD}$ & .07 & .03 & .02 & 14 & & \\
\hline
\end{tabular}

Source: own $\mathrm{N}=401 ; \mathrm{BC}=$ Biased Corrected; $\mathrm{Cl}=$ Confidence Intervals (for 5,000 bootstrap samples); S.E = Standard Error; FRS = Family Role Salience; FRCS $=$ Family Related Support from Coworkers; ${ }^{* *}=p<0.01$ level.

Based on social exchange process (Blau, 1964), considering work to family enrichment as bridge, this research proposed work to family enrichment as mediator. We found that emotional and instrumental family related social supports from coworkers enhanced the positive experiences of work to family enrichment of employees, which in turn created the sense of obligation and indebtedness to reciprocate by displaying ICBs (i.e., person \& task Focused). These results are also consistent with previous mediational studies which have incorporated work to family enrichment as bridge, based on SET (Baral \& Bhargava, 2010; Fung et al., 2013; McNall et al., 2009; Odle-Dusseau et al., 2012; Tang et al., 2014). Our study extended by testing the specific indirect effects of two types of family related social supports from coworkers on two specific citizenship behaviours. Further, for the purpose of comparison, the indirect effect of emotional support was more than the indirect effect of instrumental support on person focused ICB. This can be logically true as the emotional support components are likely to enhance relational components more through the mediational role of work to family enrichment. Regarding the indirect effect of both types of social supports on task focused ICB, again the indirect effect of emotional support was more on task focused ICB as compared to instrumental social support. It could be because of the emotional support which is engendering more positive experiences of work to family enrichment which in turn might be influencing more to the task focused ICB of an individual. Otherwise the main effect of instrumental was more on task focused ICB as compared to person focused ICB. Thus, overall regarding the indirect effects, it is emotional social support which engender slightly more work to family enrichment and in turn influences slight more to the ICBs (i.e., person \& task Focused) of employees as compared to instrumental support.

Our study also found the significant conditional indirect effect of emotional and instrumental family related social supports from coworkers on the ICBs (person \& task focused) through work to family enrichment at all levels of the moderator. The conditional 
indirect effects were low when family role salience was low and high when family role salience was high. Consistent with the work family enrichment theory (Greenhaus \& Powell, 2006), we found the significant role of family role salience as simple moderator as well as the moderator of significant conditional indirect effect of emotional and instrumental family related social supports from coworkers on the ICBs (person \& task focused) through work to family enrichment. These results provided us the useful information about when employees may experience more work to family enrichment which can influence them to reciprocate more to their fellow workers through performing person as well as task focused ICBs. These results have highlighted the value of family role salience in the life of employees. Thus, overall this study contributed by testing the significant moderated mediation model.

\section{Conclusions}

This study contributed by incorporating the role of work family enrichment theory and social exchange theory in the relationship between social support and interpersonal citizenship behavior. Methodologically, we contributed by examining a moderated mediation model. Our findings suggested that family related social supports from coworkers (i.e., both emotional and instrumental) have been effective for employee to experience work to family enrichment. Whereas, the role of emotional support has been more influential to engender work to family enrichment or enhance employees ICBs indirectly through work to family enrichment but such type of support is informal. The state of HRM practices in banking sector of Pakistan have been in infant stage, specifically banks do not have formal family related HRM practices (Khilji, 2013). In absence of formal family related HRM practices, although, coworkers have been trying their best to support each other but development of a formal procedure which can allow employees to provide social support specifically instrumental social support formally, may enhance the positive experiences of work to family enrichment more. On the basis of the findings of this research, we suggest that the organizations, specifically banking sector organizations, should pay serious attention to not only work but also family role of employees. It is important for organizations to provide the employees an environment in which employees are able to interact with each other to gain the support which is according to their work \& family needs. With regards to the mediational role of work to family enrichment, we found role of work to family enrichment like a bridge in the social supports and employees' ICBs. Through the mediational role of work to family enrichment we came to know the extent to which emotional and instrumental family related social supports from coworkers help individuals to improve their family performance and in reciprocation employees' feel obligated to help their fellow workers to improve their relational as well as task related organizational performance. An employee has to perform both roles simultaneously and if the workplace is family supportive enough than because of such positive work family enrichment experiences an employee feels obligated to reciprocate by performing ICBs (person $\&$ task focused) and to engage in the direct assistance in solving a family related problem. The emotional actions have been realized as more valuable to contribute in improvement of family performance and in turn contributing more towards the employees' relational as well as task performance. Finally, our findings suggest that all employees may not treat their families as equally important. The employees for whom their family is more salient, such employees experience more work to family enrichment through the family related social supports and also these employees in turn reciprocate more to help their follow workers by performing person as well as task focused ICBs.

Many of research studies have been conducted on employees' performance behaviour in banking sector of Pakistan (Bashir \& Ismail Ramay, 2010; Saeed et al., 2013; Ullah Bukhari, 2009). However, there are limited studies on the positive side of work family interface and neither of the studies selected banking sector employees as sample. Therefore, it is suggested to conduct more research on the positive side of work family interface in banking sector of Pakistan. This research used the cross sectional data. The future research may use the longitudinal data. This research tested work to family enrichment in general while other studies may include specific dimension of work to family enrichment (i.e., emotional, capital, development). The 
family performance measure, as proposed by Chen et al. (2014), may be tested as dependent measures. For more generalizable results, it can be expanded to some other countries with different samples.

\section{References}

Aldous, J. (1969). Occupational characteristics and males' role performance in the family. Journal of Marriage and the Family, 31(4), 707-712. https://dx.doi.org/10.2307/349312.

Baral, R., \& Bhargava, S. (2010). Workfamily enrichment as a mediator between organizational interventions for work-life balance and job outcomes. Journal of Managerial Psychology, 25(3), 274-300. https://dx.doi.org/10.1108/02683941011023749.

Barling, J., Macewen, K. E., \& Pratt, L. I. (1988). Manipulating the type and source of social support: An experimental investigation. Canadian Journal of Behavioural Science/ Revue canadienne des sciences du comportement, 20(2), 140-153. https://dx.doi. org/10.1037/h0079923.

Bashir, U., \& Ismail Ramay, M. (2010). Impact of stress on employees job performance: A study on banking sector of Pakistan. International Journal of Marketing Studies, 2(1), 122-126.

Blau, P. M. (1964). Exchange and power in social life. Transaction Publishers.

Boyar, S. L., Campbell, N. S., Mosley Jr, D. C., \& Carson, C. M. (2014). Development of a work/family social support measure. Journal of Managerial Psychology, 29(7), 901-920. https://dx.doi.org/10.1108/JMP-06-2012-0189.

Carlson, D. S., Kacmar, K. M., Wayne, J. H., \& Grzywacz, J. G. (2006). Measuring the positive side of the work-family interface: Development and validation of a work-family enrichment scale. Journal of Vocational Behavior, 68(1), 131-164. https://dx.doi. org/10.1016/j.jvb.2005.02.002.

Chen, Y.-P., Shaffer, M., Westman, M., Chen, S., Lazarova, M., \& Reiche, S. (2014). Family role performance: scale development and validation. Applied Psychology, 63(1), 190-218. https://dx.doi.org/10.1111/apps.12005.

Chiaburu, D. S., \& Harrison, D. A. (2008). Do peers make the place? Conceptual synthesis and meta-analysis of coworker effects on perceptions, attitudes, OCBs, and performance. Journal of Applied Psychology, 93(5), 1082-1103. https://dx.doi.org/10.1037/0021-9010.93.5.1082.
Cohen, S., \& Wills, T. A. (1985). Stress, social support, and the buffering hypothesis. Psychological bulletin, 98(2), 310-357. https://dx.doi.org/10.1037/0033-2909.98.2.310.

Daniel, S., \& Sonnentag, S. (2014). Work to non-work enrichment: The mediating roles of positive affect and positive work reflection. Work \& Stress, 28(1), 49-66. https://dx.doi.org /10.1080/02678373.2013.872706.

DHS, M. (2013). MEASURE DHS: Demographic and Health Surveys. Retrieved from https://dhsprogram.com/Data/.

Etzion, D. (1984). Moderating effect of social support on the stress-burnout relationship. Journal of Applied Psychology, 69(4), 615-622. https://dx.doi.org/10.1037/0021-9010.69.4.615.

Frese, M. (1999). Social support as a moderator of the relationship between work stressors and psychological dysfunctioning: a longitudinal study with objective measures. Journal of Occupational Health Psychology, 4(3), 179-192. https://dx.doi.org/10.1037/10768998.4.3.179.

Fung, N. S., Ahmad, A., \& Omar, Z. (2013). Role of Work-Family Enrichment in Improving Job Satisfaction. American Journal of Applied Sciences, 11(1), 96-104. https://dx.doi. org/10.3844/ajassp.2014.96.104.

Grandey, A., Cordeiro, B., \& Crouter, A. (2005). A longitudinal and multi-source test of the work-family conflict and job satisfaction relationship. Journal of Occupational and Organizational Psychology, 78(3), 305-323. https://dx.doi.org/10.1348/096317905x26769.

Greenhaus, J. H., \& Powell, G. N. (2006). When work and family are allies: A theory of work-family enrichment. Academy of Management Review, 31(1), 72-92. https://dx.doi.org/10.5465/AMR.2006.19379625.

Hair, J. F., Black, W. C., Babin, B. J., \& Anderson, R. E. (2010). Multivariate data analysis (7th ed.). Upper Saddle River, NJ: Prentice Hall.

Hameed, I., Roques, O., \& Arain, G. A. (2013). Nonlinear moderating effect of tenure on organizational identification (OID) and the subsequent role of OID in fostering readiness for change. Group \& Organization Management, 38(1), 101-127. https://dx.doi. org/10.1177/1059601112472727.

Hayes, A. F. (2012). PROCESS: A versatile computational tool for observed variable mediation, moderation, and conditional process modeling [White paper]. Retrieved from http://www.afhayes.com/public/process2012.pdf. 
Hobfoll, S. E. (1988). The ecology of stress. Taylor \& Francis. https://dx.doi.org/10.1002/ smi.2460050415.

House, J. S. (1981). Work, stress and social support. Reading, MA: Addison-Wesley.

House, J. S., Kahn, R. L., McLeod, J. D., $\&$ Williams, D. (1985). Measures and concepts of social support. In S. Cohen, \& S. L. Syme (Eds.), Social support and health (pp. 83-108). New York: Academic Press.

Jaga, A., \& Bagraim, J. (2011). The relationship between work-family enrichment and work-family satisfaction outcomes. South African Journal of Psychology, 41(1), 52-62. https://dx.doi.org/10.1177/008124631104100106.

Jawahar, I., \& Stone, T. H. (2015). Do career satisfaction and support mediate the effects of justice on organizational citizenship behaviour and counterproductive work behaviour? Canadian Journal of Administrative Sciences/Revue Canadienne des Sciences de l'Administration, 34(3), 215-228. https://dx.doi. org/10.1002/cjas. 1350 .

Kalliath, P. (2014). Is Work-Family Enrichment an Antidote to Experiences of Psychological Strain Among Australian Social Workers? An Empirical Study. Australian Social Work, 67(3), 332-347. https://dx.doi.org/10.108 0/0312407X.2013.825302.

Kelloway, E. K., Gottlieb, B. H., \& Barham, L. (1999). The source, nature, and direction of work and family conflict: a longitudinal investigation. Journal of Occupational Health Psychology, 4(4), 337-346. https://dx.doi. org/10.1037//1076-8998.4.4.337.

Khilji, S. E. (2013). Human resource management in Pakistan. In P. S. Budhwar, \& Y. A. Debrah (Eds.), Human resource management in developing countries (pp. 102-120). Routledge.

Kiewitz, C., Restubog, S. L. D., Zagenczyk, T., \& Hochwarter, W. (2009). The interactive effects of psychological contract breach and organizational politics on perceived organizational support: Evidence from two longitudinal studies. Journal of Management Studies, 46(5), 806-834. https://dx.doi. org/10.1111/j.1467-6486.2008.00816.x.

Lysaght, R., Fabrigar, L., Larmour-Trode, S., Stewart, J., \& Friesen, M. (2012). Measuring workplace social support for workers with disability. Journal of occupational rehabilitation, 22(3), 376-386. https://dx.doi.org/10.1007/ s10926-012-9357-1.
Malecki, C. K., \& Demaray, M. K. (2003). What Type of Support Do They Need? Investigating Student Adjustment as Related to Emotional, Informational, Appraisal, and Instrumental Support. School Psychology Quarterly, 18(3), 231-252. https://dx.doi. org/10.1521/scpq.18.3.231.22576.

Marks, S. R. (1977). Multiple roles and role strain: Some notes on human energy, time and commitment. American Sociological Review, 42(6), 921-936. https://dx.doi.org/10.2307/2094577.

Mauno, S., \& Rantanen, M. (2013). Contextual and dispositional coping resources as predictors of work-family conflict and enrichment: which of these resources or their combinations are the most beneficial? Journal of family and economic issues, 34(1), 87-104. https://dx.doi.org/10.1007/s10834-012-9306-3.

McNall, L. A., Masuda, A. D., \& Nicklin, J. M. (2009). Flexible work arrangements, job satisfaction, and turnover intentions: The mediating role of work-to-family enrichment. The Journal of Psychology, 144(1), 61-81. https:// dx.doi.org/10.1080/00223980903356073.

McNall, L. A., Nicklin, J. M., \& Masuda, A. D. (2010). A meta-analytic review of the consequences associated with workfamily enrichment. Journal of Business and Psychology, 25(3), 381-396. https://dx.doi. org/10.1007/s10869-009-9141-1.

Nelson, M., \& Brice, J. (2008). Emotional and informational social support: Exploring contrasting influences on human resource management innovation. Journal of Organizational Culture, Communications and Conflict, 12(1).

Odle-Dusseau, H. N., Britt, T. W., \& GreeneShortridge, T. M. (2012). Organizational work-family resources as predictors of job performance and attitudes: The process of work-family conflict and enrichment. Journal of Occupational Health Psychology, 17(1), 28-40. https://dx.doi.org/10.1037/a0026428.

Osseiran-Waines, N., \& Elmacian, S. (1994). Types of social support: Relation to stress and academic achievement among prospective teachers. Canadian Journal of Behavioural Science/Revue canadienne des sciences du comportement, 26(1), 1-20. https:// dx.doi.org/10.1037/0008-400X.26.1.1.

Pallant, J. (2010). SPSS survival manual: A step by step guide to data analysis using SPSS. Open University Press.

Podsakoff, P. M., MacKenzie, S. B., Lee, J.Y., \& Podsakoff, N. P. (2003). Common method 
biases in behavioral research: A critical review of the literature and recommended remedies. Journal of Applied Psychology, 88(5), 879-903. https://dx.doi.org/10.1037/0021-9010.88.5.879.

Powell, G. N., \& Greenhaus, J. H. (2006). Is the opposite of positive negative? Untangling the complex relationship between work-family enrichment and conflict. Career Development International, 11(7), 650-659. https://dx.doi. org/10.1108/13620430610713508.

Preacher, K. J., Rucker, D. D., \& Hayes, A. F. (2007). Addressing moderated mediation hypotheses: Theory, methods, and prescriptions. Multivariate behavioral research, 42(1), 185-227. https://dx.doi.org/10.1080/00273170701341316.

Rees, T., \& Hardy, L. (2004). Matching social support with stressors: Effects on factors underlying performance in tennis. Psychology of Sport and Exercise, 5(3), 319-337. https://dx.doi.org/10.1016/S1469-0292(03)00018-9.

Restubog, S. L. D., Bordia, P., Tang, R. L., \& Krebs, S. A. (2010). Investigating the moderating effects of leader-member exchange in the psychological contract breachemployee performance relationship: A test of two competing perspectives. British Journal of Management, 21(2), 422-437. https://dx.doi. org/10.1111/j.1467-8551.2009.00673.x.

Restubog, S. L. D., Hornsey, M. J., Bordia, P., \& Esposo, S. R. (2008). Effects of psychological contract breach on organizational citizenship behaviour: Insights from the group value model. Journal of Management Studies, 45(8), 1377-1400. https://dx.doi.org/10.1111/ j.1467-6486.2008.00792.x.

Saeed, R., Mussawar, S., Lodhi, R. N., Iqbal, A., Nayab, H. H., \& Yaseen, S. (2013). Factors affecting the performance of employees at work place in the banking sector of pakistan. Middle-East Journal of Scientific Research, 17(9), 1200-1208. https://dx.doi.org/10.5829/ idosi.mejsr.2013.17.09.12256.

Saunders, M. N., Saunders, M., Lewis, P., \& Thornhill, A. (2011). Research methods for business students, 5/e. Pearson Education India.

Settoon, R. P., \& Mossholder, K. W. (2002). Relationship quality and relationship context as antecedents of person-and task- focused interpersonal citizenship behavior. Journal of Applied Psychology, 87(2), 255-267. https://dx.doi.org/10.1037//0021-9010.87.2.255.

Sieber, S. D. (1974). Toward a theory of role accumulation. American Sociological Review, 567-578. https://dx.doi.org/10.2307/2094422.

Siu, O. L., Bakker, A. B., Brough, P., Lu, C.-q., Wang, H., Kalliath, T., . . . Timms, C. (2014). A Three-wave Study of Antecedents of Work-Family Enrichment: The Roles of Social Resources and Affect. Stress and Health, 31(4), 306-314. https://dx.doi.org/10.1002/smi.2556.

Suazo, M. M. (2011). The Impact of Affect and Social Exchange on Outcomes of Psychological Contract Breach. Journal of Managerial Issues, 23(2), 190-205.

Tang, S. W., Siu, O. I., \& Cheung, F. (2014). A study of work-family enrichment among Chinese employees: The mediating role between work support and job satisfaction. Applied Psychology, 63(1), 130-150. https:// dx.doi.org/10.1111/j.1464-0597.2012.00519.x.

Ullah Bukhari, Z. (2009). Key antecedents of organizational citizenship behavior (OCB) in the banking sector of Pakistan. International Journal of Business and Management, 3(12), 106-115. https://dx.doi.org/10.5539/ijbm. v3n12p106.

Wadsworth, L. L., \& Owens, B. P. (2007). The effects of social support on work-family enhancement and work-family conflict in the public sector. Public Administration Review, 67(1), 75-87. https://dx.doi.org/10.1111/j.15406210.2006.00698.x.

PhD Scholar Aneel Kumar

Sukkur Institute of Business Administration Pakistan aneelkumar.phd@iba-suk.edu.pk

Assist. Prof. Khalil Ahmed Channa

Sukkur Institute of Business Administration Pakistan khalilchanna@iba-suk.edu.pk

Prof. Niaz Ahmed Bhutto Sukkur Institute of Business Administration Pakistan niaz@iba-suk.edu.pk 


\title{
Abstract
}

\section{RECIPROCATION AT WORK: THE ROLE OF WORK TO FAMILY ENRICHMENT AND FAMILY ROLE SALIENCE}

\author{
Aneel Kumar, Khalil Ahmed Channa, Niaz Ahmed Bhutto
}

This study investigated the main and conditional indirect effects of emotional and instrumental family related social supports from coworkers on person and task focused interpersonal citizenship behavior (ICBs). We incorporated work to family enrichment as mediator and family role salience as moderator in conditional indirect effect paths. Primary data were collected through the survey questionnaire in dyads from the employees and their immediate supervisors $(N=401)$. The results showed that the main and conditional indirect effects of emotional and instrumental family related social supports from coworkers were positive and significant on both ICBs (person and task focused). In comparison to instrumental support, the main effect of emotional support was more on person focused ICB. Whereas, in comparison to emotional support, the main effect of instrumental support was more on task focused ICB, as hypothesized. Work to family enrichment was found as mediator and family role salience as moderator in conditional indirect effect paths. This study establishes work family enrichment as a bridge in the social exchange process. The resources of emotional and instrumental family related support form coworkers' engendered work to family enrichment, which in turn created the sense of obligation in the employees to reciprocate by performing person and task focused interpersonal citizenship behavior in the workplace. Further the employees high on family role salience experienced work to family enrichment more, due to support resources, and in turn reciprocated more interpersonal citizenship behaviors. Overall, this study contributed by examining a moderated mediation model, by testing work to family enrichment as mediator and family role salience as the boundary condition in relationship between two specific types of social support (i.e., emotional and instrumental) and two specific types of interpersonal citizenship behavior (i.e., person and task focused).

Key Words: Emotional, instrumental family related social support, work to family enrichment, family role salience and person and task focused interpersonal citizenship behavior.

JEL Classification: M5, M540.

DOI: 10.15240/tul/001/2018-2-007 